\title{
ARTICLE
}

\section{Early pregnancy vitamin $D$ and the risk of adverse maternal and infant outcomes: a retrospective cohort study}

\author{
Geng-dong Chen ${ }^{1+}$, Ting-ting Pang ${ }^{2 \dagger}$, Peng-sheng Li ${ }^{1}$, Zi-xing Zhou', Dong-xin Lin ${ }^{1}$, Da-zhi Fan',
} Xiao-ling Guo ${ }^{1}$ and Zheng-ping Liu ${ }^{1^{*}}$ (i)

\begin{abstract}
Background: Previous evidence has suggested that lower gestational vitamin D levels might increase the risks of adverse pregnancy and birth outcomes. The results remain inconsistent and require further exploration.

Methods: A total of 2814 Chinese mother-infant pairs were included in this retrospective cohort study. Serum concentrations of $25(\mathrm{OH}) \mathrm{D}$ were reviewed in early pregnancy $(16.3 \pm 2.3$ weeks). Outcomes of maternal gestational diabetes mellitus (GDM), cesarean section, fetal distress, preterm birth, low birth weight (LBW), and macrosomia were extracted from the medical records. Cox regression analysis was used to explore these associations.

Results: In total, $19.3 \%$ of mothers were pregnant at an advanced age ( $\geq 35$ years), and $40.3 \%$ of pregnant women had vitamin D deficiency (<50 nmol/L). After adjusting for potential covariates, the hazard ratio (HR) (95\% Cl) per standard deviation (SD) increase of serum $25(\mathrm{OH}) \mathrm{D}$ concentrations was $0.86(0.779,0.951)$ for GDM, $0.844(0.730$, 0.976) for preterm birth, and $0.849(0.726,0.993)$ for LBW. Similar protective associations were found for GDM, cesarean section, and preterm birth for a better vitamin D status when compared with vitamin D deficiency.
\end{abstract}

Conclusion: Higher early pregnancy vitamin D was associated with a lower risk of GDM, cesarean section, preterm birth, and LBW.

Keywords: 25(oh)d, Vitamin D, Pregnancy, Maternal outcome, Infant outcome

\section{Background}

Vitamin D is a secosteroid hormone that is well known for its physiological function in maintaining bone metabolism and health. A high prevalence of vitamin D deficiency (usually defined as serum $25(\mathrm{OH}) \mathrm{D}$ levels $<50 \mathrm{nmol} / \mathrm{L}$ ) has been found in pregnant women globally, especially in developing countries [1], including China [2, 3]. Increasing evidence has suggested that vitamin D sufficiency is important

\footnotetext{
* Correspondence: liuzphlk81@outlook.com

${ }^{\dagger}$ Geng-dong Chen and Ting-ting Pang contributed equally to this work. ${ }^{1}$ Foshan Institute of Fetal Medicine, Department of Obstetrics, Affiliated Foshan Maternity \& Child Healthcare Hospital, Southern Medical University, Foshan 528000, Guangdong, China

Full list of author information is available at the end of the article
}

for the prevention of pregnancy complications in mothers and adverse fetal birth outcomes [4, 5], although divergent results have been reported in other studies [3, 6-8]. Several systematic reviews based on randomized clinical trials or observational studies have suggested that lower vitamin D status contribute to adverse outcomes such as preeclampsia [9], gestational diabetes mellitus (GDM) [10,11], low birth weight (LBW) [12], and preterm birth [13]. However, increasing evidence shows different associations [3, 7, 14], and no definitive conclusion has yet been made [4]. Several problems remain to be solved by further studies: the heterogeneity of associations from diverse areas and populations with different vitamin D status serve as evidence when making guidelines for specific regions; the

(c) The Author(s). 2020 Open Access This article is licensed under a Creative Commons Attribution 4.0 International License, which permits use, sharing, adaptation, distribution and reproduction in any medium or format, as long as you give appropriate credit to the original author(s) and the source, provide a link to the Creative Commons licence, and indicate if changes were made. The images or other third party material in this article are included in the article's Creative Commons licence, unless indicated otherwise in a credit line to the material. If material is not included in the article's Creative Commons licence and your intended use is not permitted by statutory regulation or exceeds the permitted use, you will need to obtain permission directly from the copyright holder. To view a copy of this licence, visit http://creativecommons.org/licenses/by/4.0/ The Creative Commons Public Domain Dedication waiver (http://creativecommons.org/publicdomain/zero/1.0/) applies to the data made available in this article, unless otherwise stated in a credit line to the data. 
observation or supplementation of vitamin D in the third trimester in many studies might present the problem of causal inference or miss the practical period for the intervention. In addition, the results from early trimesters might be helpful and more important for the early prevention of adverse outcomes.

In addition, it has been suggested that the risk of adverse complications or birth outcomes increases as maternal age increases [15-17]. With the change of population policy in China, the percentage of women pregnant at an advanced age ( $>35$ years) has increased, and proper strategies are urgently needed for the prevention of adverse complications [18]. However, whether the influence of vitamin $\mathrm{D}$ on maternal and infant outcomes remained the same for women pregnant at young ( $<35$ years $)$ and advanced ages remains unclear, and more studies are needed to better illustrate the problem.

We investigated the relationship between early gestational serum 25(OH)D concentrations and several adverse maternal and infant outcomes in a retrospective cohort study including 2814 Chinese mother-infant pairs. Our results provide further evidence for clinical recommendations on the early prevention of related adverse outcomes in this field.

\section{Methods}

The study used data that were gathered from a large center, Affiliated Foshan Maternity \& Child Healthcare Hospital, Southern Medical University, Foshan City, Guangdong Province, China, from September 1, 2017, to July 31,2018 . The hospital is the largest gynecology and obstetrics center in Foshan City and covers a large population of 7.7 million people. The included subjects were women who underwent early pregnancy serum vitamin D measurement ( $\leq 20$ gestational weeks) and delivered their infants at the hospital. The exclusion criteria included twin or higher-order multiple pregnancies; serious diseases, such as type 2 diabetes mellitus, cardiovascular diseases, thyroid disorder, and cancer, that occurred before pregnancy. Ultimately, a total 2814 mother-infant pairs were included in this study. The study was approved by the ethics committee of Affiliated Foshan Maternity \& Child Healthcare Hospital, Southern Medical University.

\section{Data collection}

Vitamin D data from the clinical laboratory were reviewed. Blood samples were collected during the regular obstetric check-ups and immediately measured by a clinical laboratory without being frozen. Serum concentrations of $25(\mathrm{OH}) \mathrm{D}, 25(\mathrm{OH}) \mathrm{D}_{2}$, and $25(\mathrm{OH}) \mathrm{D}_{3}$ were detected using colloidal gold immunochromatography. Commercial kits were obtained from Mei Ning Kang Cheng Bio Tec Inc. The intra-assay and inter-assay coefficients of variation were less than $15 \%$.
Outcomes including GDM, cesarean section, fetal distress, preterm birth, low birth weight, and macrosomia were extracted from medical records and reexamined by two independent staff members. The disease diagnoses were made by professional doctors with the same standardization criteria and were extracted from the medical records. Gestational hypertension, preeclampsia, or eclampsia was not included because of the lack of available cases. An oral glucose tolerance test was performed from 24 to 28 gestational weeks, and GDM was diagnosed if the subjects met any of the following criteria: fasting blood glucose $\geq 5.1 \mathrm{mmol} / \mathrm{L}$; one-hour blood glucose postoral sugar $\geq 10.0 \mathrm{mmol} / \mathrm{L}$; or two-hour blood glucose postoral sugar $\geq 8.5 \mathrm{mmol} / \mathrm{L}$. Preterm birth was defined as delivery at $\geq 28$ but $<37$ gestational weeks. LBW was diagnosed if the neonatal birth weight $<2500$ $\mathrm{g}$, while a neonatal birth weight $\geq 4000 \mathrm{~g}$ was defined as macrosomia. Other variables, including the maternal age, body mass index (BMI), gestational age, parity, season of blood collection, and time of delivery, were also extracted from the medical records.

\section{Statistical analyses}

Continuous variables were represented by the mean \pm standard deviation (SD) or median (interquartile range) and tested by Student's t-test. Categorical variables were represented by frequencies (percentage) and tested by the chi-square test. Cox regression analysis was performed to explore the associations between vitamin D and maternal or infant outcomes. Serum concentrations of $25(\mathrm{OH}) \mathrm{D}, 25(\mathrm{OH}) \mathrm{D}_{2}$, and $25(\mathrm{OH}) \mathrm{D}_{3}$ were first $\mathrm{Z}$ standardized before being included in the regression. Vitamin D deficiency was defined as serum 25(OH)D levels of $<50 \mathrm{nmol} / \mathrm{L}$. Two different models were tested, with Model 1 as a univariate model without adjustment and Model 2 adjusted for maternal age, BMI, parity, and season the blood was collected and measured. Stratified analyses were performed according to the gestational age (young: $<35$ years; advanced: $\geq 35$ years). All the analyses were performed using SPSS software version 21.0 (SPSS Inc. Chicago, IL, USA). A two-sided $P$ value of less than 0.05 was considered statistically significant.

\section{Results}

A total 2814 mother-infant pairs were included in this study. A high prevalence of gestational vitamin D deficiency $(40.3 \%)$ was discovered in the mothers. Even in subjects without vitamin D deficiency, the highest serum $25(\mathrm{OH}) \mathrm{D}$ concentration was only $92.2 \mathrm{nmol} / \mathrm{L}$. Compared with women pregnant at a younger age, the subjects with advanced age of pregnancy ( $\geq 35$ years) tended to have a higher BMI, parity, higher percentage of vitamin D deficiency, higher incidence of GDM, cesarean section, preterm birth, and LBW, but a lower gestational 
age, lower serum $25(\mathrm{OH}) \mathrm{D}$ and $25(\mathrm{OH}) \mathrm{D}_{3}$ concentrations, lower incidence of fetal distress, and lower incidence of macrosomia (Table 1).

As shown in Table 2, although the 25(OH)D concentrations were statistically higher in spring and summer than those in autumn and winter, only small difference of $25(\mathrm{OH}) \mathrm{D}$ values $(0.39$ to $3.2 \mathrm{nmol} / \mathrm{L})$ was observed between different seasons, especially for $25(\mathrm{OH}) \mathrm{D}_{2}$. Significant protective associations were found between the vitamin D levels and GDM and preterm birth. After adjusting for potential covariates (Table 3), higher $25(\mathrm{OH}) \mathrm{D}$ concentrations (per one SD increase) were associated with a $13.9 \%$ (HR: $0.861,95 \%$ CI: $0.779,0.951$ ) decrease in the GDM risk, a $15.6 \%$ (HR: $0.844,95 \%$ CI: $0.730,0.976)$ decrease in the preterm birth risk, and a 15.1\% (HR: 0.849, 95\% CI: 0.726, 0.993) decrease in the LBW risk. Similar protective results were also found for
$25(\mathrm{OH}) \mathrm{D}_{2}$ and $25(\mathrm{OH}) \mathrm{D}_{3}$, but the associations tended to be more pronounced for $25(\mathrm{OH}) \mathrm{D}_{2}$. Null associations between vitamin $\mathrm{D}$ and cesarean section, fetal distress, and macrosomia were observed in all the subjects. Maternal serum 25(OH)D levels $\geq 50 \mathrm{nmol} / \mathrm{L}$ were associated with a $25.0 \%$ decrease in the GDM risk, a $15.2 \%$ decrease in the cesarean section risk, and a $26.8 \%$ decrease in the preterm birth risk, but the trend did not hold with the other outcomes, compared with those with vitamin D deficiency (Table 4).

After stratification by gestational age (Table 5), higher levels of vitamin D were associated with a $15.9 \%$ lower risk of GDM in those < 35 years. In contrast, a protective association of vitamin $\mathrm{D}$ with low birth weight was found for women pregnant at $\geq 35$ years but not $<35$ years. However, no significant interactions were discovered $(P$-interaction $=0.095 \sim 0.986)$.

Table 1 Characteristic of subjects

\begin{tabular}{|c|c|c|c|c|}
\hline & Total $(N=2814)$ & $<35$ years $(N=2272)$ & $\geq 35$ years $(N=542)$ & $P$ \\
\hline Age, years & $30.5 \pm 4.98$ & $28.7 \pm 3.47$ & $38.2 \pm 2.30$ & $<0.001$ \\
\hline $\mathrm{BMl}, \mathrm{kg} / \mathrm{cm}^{2}$ & $26.6 \pm 3.12$ & $26.5 \pm 3.11$ & $27.4 \pm 3.04$ & $<0.001$ \\
\hline Gestational age, weeks & $38.7 \pm 1.84$ & $38.8 \pm 1.80$ & $38.2 \pm 1.98$ & $<0.001$ \\
\hline Parity, times & $1.45 \pm 0.56$ & $1.35 \pm 0.53$ & $1.88 \pm 0.44$ & $<0.001$ \\
\hline Neonatal birth weight, kg & $3.15 \pm 0.45$ & $3.15 \pm 0.44$ & $3.14 \pm 0.46$ & 0.654 \\
\hline 25(OH)D, nmol/L & $53.1 \pm 9.99$ & $53.5 \pm 9.98$ & $51.9 \pm 9.89$ & 0.002 \\
\hline $25(\mathrm{OH}) \mathrm{D}_{2}, \mathrm{nmol} / \mathrm{L}$ & $5.34 \pm 1.71$ & $5.34 \pm 1.00$ & $5.33 \pm 3.32$ & 0.884 \\
\hline $25(\mathrm{OH}) \mathrm{D}_{3}, \mathrm{nmol} / \mathrm{L}$ & $47.8 \pm 8.99$ & $48.0 \pm 8.98$ & $46.7 \pm 8.95$ & 0.002 \\
\hline Vitamin D deficiency, N (\%) & & & & 0.043 \\
\hline Yes & $1133(40.3)$ & $894(39.3)$ & $239(44.1)$ & \\
\hline No & $1681(59.7)$ & $1378(60.7)$ & $303(55.9)$ & \\
\hline Gestational diabetes mellitus, N (\%) & & & & $<0.001$ \\
\hline Yes & $424(15.1)$ & $279(12.3)$ & $145(26.8)$ & \\
\hline No & $2390(84.9)$ & $1993(87.7)$ & $397(73.2)$ & \\
\hline Caesarean section, N (\%) & & & & $<0.001$ \\
\hline Yes & 1368 (48.6) & $1021(44.9)$ & $347(64.0)$ & \\
\hline No & $1446(51.4)$ & $1251(55.1)$ & $195(36.0)$ & \\
\hline Fetal distress in uterus, N (\%) & & & & 0.001 \\
\hline Yes & $282(10.0)$ & $249(11.0)$ & $33(6.1)$ & \\
\hline No & $2532(90.0)$ & $2023(89.0)$ & $509(93.9)$ & \\
\hline Preterm birth, N (\%) & & & & $<0.001$ \\
\hline Yes & $195(6.90)$ & $135(5.90)$ & $60(11.1)$ & \\
\hline No & $2619(93.1)$ & $2137(94.1)$ & $482(88.9)$ & \\
\hline Low birth weight, N (\%) & & & & 0.025 \\
\hline Yes & $166(5.90)$ & $123(5.40)$ & $43(7.90)$ & \\
\hline No & $2648(94.1)$ & $2149(94.6)$ & $499(92.1)$ & \\
\hline Macrosomia, N (\%) & & & & 0.030 \\
\hline Yes & $74(2.60)$ & $67(2.90)$ & $7(1.30)$ & \\
\hline No & 2740 (97.4) & 2205 (97.1) & 535 (98.7) & \\
\hline
\end{tabular}


Table 2 Seasonal difference between serum vitamin D indicators

\begin{tabular}{llll}
\hline & \multicolumn{2}{l}{ Detected Season } & $P$ \\
\cline { 2 - 3 } & spring \& summer & autumn \& winter & \\
\hline $25(\mathrm{OH}) \mathrm{D}, \mathrm{nmol} / \mathrm{L}$ & $55.2 \pm 10.2$ & $52.0 \pm 9.68$ & $<0.001$ \\
$25(\mathrm{OH}) \mathrm{D}_{2}, \mathrm{nmol} / \mathrm{L}$ & $5.59 \pm 2.53$ & $5.20 \pm 0.97$ & $<0.001$ \\
$25(\mathrm{OH}) \mathrm{D}_{3}, \mathrm{nmol} / \mathrm{L}$ & $49.6 \pm 9.19$ & $46.7 \pm 8.71$ & $<0.001$ \\
\hline
\end{tabular}

\section{Discussion}

In this retrospective cohort study including 2814 Chinese mother-infant pairs, protective associations were found for higher serum 25(OH)D concentrations with GDM, cesarean section, postpartum hemorrhage, preterm birth, and low birth weight, but not for the other outcomes. The results for $25(\mathrm{OH}) \mathrm{D}_{2}$ tended to be more pronounced than those for $25(\mathrm{OH}) \mathrm{D}_{3}$. Interestingly, higher serum vitamin $\mathrm{D}$ contributes to a higher risk of postpartum anemia in women pregnant at a young age but not in advanced years.

In this population with a high prevalence of vitamin $\mathrm{D}$ deficiency, better serum vitamin D status contributed to a lower risk of GDM. This result was consistent with several other studies. A 49 to $85 \%$ higher risk of GDM was observed for pregnant women with insufficient or deficient vitamin D status in three systematic reviews and meta-analyses based on observational studies or clinical trials $[10,12,19]$. In a large randomized control trial (RCT) based on 800 Iranian women, the intervention of $25(\mathrm{OH}) \mathrm{D}_{3}$ was associated with lower risk of GDM [20]. The results were further supported by several other prospective cohort studies [21, 22]. However, null associations were found between the vitamin $\mathrm{D}$ status or supplements and GDM in a systematic review based on five randomized trials including 1030 subjects [7], a nested case-control study of 5109 women [23], and a large prospective study including 2382 mother-child pairs [14]. Additionally, two studies found detrimental associations of higher vitamin D levels with GDM, but the effects were tiny (1.7\%) [3] or restricted to specific ethnicities (Hispanic) [6].

Consistent with our results, the protective association of maternal vitamin D status with a lower risk of preterm or low birth weight has also been reported in several studies. An inverse dose-response relation of vitamin D status was found for preterm birth in a systematic review and meta-analysis based on longitudinal studies [24]. Rostami et al. reported that a $25(\mathrm{OH}) \mathrm{D}_{3}$ intervention of monthly 50,000 IU could be beneficial for the prevention of preterm delivery in an RCT of 800 Iranian women [20]. In a large prospective cohort including 3658 motheroffspring pairs, the risk of low birth weight was 12.3 (95\% CI: $4.47,33.89)$ and 3.15 (95\% CI: 1.06, 9.39) among subjects with vitamin $\mathrm{D}$ deficiency and insufficiency, respectively [25]. Higher maternal serum $25(\mathrm{OH}) \mathrm{D}$ was positively

Table 3 Associations between early pregnant serum vitamin D concentrations and maternal \& infant outcomes

\begin{tabular}{|c|c|c|c|c|c|c|c|c|c|}
\hline & \multicolumn{3}{|c|}{$25(\mathrm{OH}) \mathrm{D}^{\mathrm{a}}$} & \multicolumn{3}{|c|}{$25(\mathrm{OH}) \mathrm{D}_{2}{ }^{\mathrm{a}}$} & \multicolumn{3}{|c|}{$25(\mathrm{OH}) \mathrm{D}_{3}{ }^{\mathrm{a}}$} \\
\hline & $H R$ & $95 \% \mathrm{Cl}$ & P & $H R$ & $95 \% \mathrm{Cl}$ & $P$ & $H R$ & $95 \% \mathrm{Cl}$ & P \\
\hline \multicolumn{10}{|c|}{ Gestational diabetes mellitus } \\
\hline Model 1 & 0.832 & $(0.754,0.919)$ & $<0.001$ & 0.734 & $(0.621,0.867)$ & $<0.001$ & 0.833 & $(0.754,0.919)$ & $<0.001$ \\
\hline Model 2 & 0.861 & $(0.779,0.951)$ & 0.003 & 0.776 & $(0.656,0.918)$ & 0.003 & 0.861 & $(0.779,0.952)$ & 0.003 \\
\hline \multicolumn{10}{|c|}{ Caesarean section } \\
\hline Model 1 & 0.923 & $(0.873,0.975)$ & 0.004 & 0.954 & $(0.883,1.032)$ & 0.243 & 0.923 & $(0.873,0.975)$ & 0.004 \\
\hline Model 2 & 0.957 & $(0.905,1.012)$ & 0.122 & 0.981 & $(0.929,1.035)$ & 0.480 & 0.957 & $(0.905,1.012)$ & 0.120 \\
\hline \multicolumn{10}{|l|}{ Fetal distress } \\
\hline Model 1 & 0.931 & $(0.824,1.051)$ & 0.246 & 0.885 & $(0.723,1.084)$ & 0.239 & 0.930 & $(0.824,1.050)$ & 0.244 \\
\hline Model 2 & 0.941 & $(0.833,1.064)$ & 0.333 & 0.903 & $(0.736,1.107)$ & 0.326 & 0.941 & $(0.833,1.064)$ & 0.333 \\
\hline \multicolumn{10}{|c|}{ Preterm birth } \\
\hline Model 1 & 0.840 & $(0.727,0.970)$ & 0.017 & 0.745 & $(0.585,0.950)$ & 0.017 & 0.839 & $(0.727,0.969)$ & 0.017 \\
\hline Model 2 & 0.844 & $(0.730,0.976)$ & 0.022 & 0.752 & $(0.589,0.959)$ & 0.022 & 0.844 & $(0.730,0.975)$ & 0.021 \\
\hline \multicolumn{10}{|c|}{ Low birth weight } \\
\hline Model 1 & 0.866 & $(0.741,1.012)$ & 0.070 & 0.785 & $(0.604,1.020)$ & 0.070 & 0.866 & $(0.741,1.012)$ & 0.069 \\
\hline Model 2 & 0.849 & $(0.726,0.993)$ & 0.041 & 0.759 & $(0.583,0.988)$ & 0.041 & 0.849 & $(0.726,0.993)$ & 0.040 \\
\hline \multicolumn{10}{|l|}{ Macrosomia } \\
\hline Model 1 & 1.078 & $(0.849,1.369)$ & 0.538 & 1.007 & $(0.857,1.185)$ & 0.930 & 1.077 & $(0.848,1.368)$ & 0.541 \\
\hline Model 2 & 1.148 & $(0.893,1.475)$ & 0.281 & 1.031 & $(0.900,1.182)$ & 0.657 & 1.147 & $(0.893,1.475)$ & 0.282 \\
\hline
\end{tabular}

Cox regression analysis were operated for exploration of associations. Model 1: without adjustment. Model 2: adjusted for age, BMI, parity, season of blood collected. a: Per one SD increase 
Table 4 Associations between vitamin D status and maternal \& infant outcomes

\begin{tabular}{|c|c|c|c|c|}
\hline & \multicolumn{4}{|l|}{$25(\mathrm{OH}) \mathrm{D}$} \\
\hline & & $H R$ & $95 \% \mathrm{Cl}$ & $P$ \\
\hline \multirow[t]{2}{*}{ Gestational diabetes mellitus } & $<50 \mathrm{nmol} / \mathrm{L}$ & 1.000 & & \\
\hline & $\geq 50 \mathrm{nmol} / \mathrm{L}$ & 0.750 & $(0.618,0.909)$ & 0.003 \\
\hline \multirow[t]{2}{*}{ Caesarean section } & $<50 \mathrm{nmol} / \mathrm{L}$ & 1.000 & & \\
\hline & $\geq 50 \mathrm{nmol} / \mathrm{L}$ & 0.848 & $(0.761,0.945)$ & 0.003 \\
\hline \multirow[t]{2}{*}{ Fetal distress } & $<50 \mathrm{nmol} / \mathrm{L}$ & 1.000 & & \\
\hline & $\geq 50 \mathrm{nmol} / \mathrm{L}$ & 0.807 & $(0.636,1.023)$ & 0.076 \\
\hline \multirow[t]{2}{*}{ Preterm birth } & $<50 \mathrm{nmol} / \mathrm{L}$ & 1.000 & & \\
\hline & $\geq 50 \mathrm{nmol} / \mathrm{L}$ & 0.732 & $(0.551,0.972)$ & 0.031 \\
\hline \multirow[t]{2}{*}{ Low birth weight } & $<50 \mathrm{nmol} / \mathrm{L}$ & 1.000 & & \\
\hline & $\geq 50 \mathrm{nmol} / \mathrm{L}$ & 0.747 & $(0.549,1.016)$ & 0.063 \\
\hline \multirow[t]{2}{*}{ Macrosomia } & $<50 \mathrm{nmol} / \mathrm{L}$ & 1.000 & & \\
\hline & $\geq 50 \mathrm{nmol} / \mathrm{L}$ & 0.967 & $(0.595,1.570)$ & 0.892 \\
\hline
\end{tabular}

Cox regression analysis were operated for exploration of associations, and adjusted for covariates including: age, BMI, parity, season of blood collected

associated with higher birth weight in a study of United Arab Emirates [26], and supplementation of vitamin D at a dose of $4000 \mathrm{IU} / \mathrm{d}$ was optimal and safe for mothers and their infants in United Arab Emirates [27]. However, null or detrimental associations were also reported in other studies. Although vitamin $\mathrm{D}$ increased the mean birth weight, it did not significantly reduce the risk of low birth weight or preterm birth in a meta-analysis based on randomized trials [28]; these results were further supported by another update study [7]. In addition, higher 25(OH)D concentrations were found to increase the $3.9 \%$ risk of preterm delivery in a prospective study of 2960 pregnant Chinese women [3].

Gestational vitamin D deficiency was found to be associated with a 2-fold increased risk of cesarean section in a cohort of 1153 low-income pregnant women [29]. Within a cohort of 253 women from the United States, for women with $25(\mathrm{OH}) \mathrm{D}$ concentrations lower than $37.5 \mathrm{nmol} / \mathrm{L}$, the risk of a primary cesarean section was almost 3.84 times higher [30]. These results were consistent with ours. However, a meta-analysis of 17 trials (3240 subjects) found null associations of vitamin D supplements with cesarean section [7].

Much heterogeneity exists in the previous evidence in this field, and there may be several factors that partly explain these differences. First, most of the randomized trials included had a small sample size and were of low quality. Most subjects included in the trials had sufficient vitamin D status $(\geq 75 \mathrm{nmol} / \mathrm{L})$, and a further dose of a 400 or $600 \mathrm{IU} / \mathrm{d}$ supplement might have attenuated

Table 5 Subclass analysis of relationship between serum vitamin D concentrations and related outcomes stratified by gestational age

\begin{tabular}{|c|c|c|c|c|c|c|c|c|c|c|c|c|c|}
\hline & & \multicolumn{3}{|c|}{$25(\mathrm{OH}) \mathrm{D}^{\mathrm{a}}$} & \multirow[t]{2}{*}{$p^{b}$} & \multicolumn{3}{|c|}{$25(\mathrm{OH}) \mathrm{D}_{2}{ }^{\mathrm{a}}$} & \multirow[t]{2}{*}{$p^{b}$} & \multicolumn{3}{|c|}{$25(\mathrm{OH}) \mathrm{D}_{3}{ }^{\mathrm{a}}$} & \multirow[t]{2}{*}{$p^{b}$} \\
\hline & & $H R$ & $95 \% \mathrm{Cl}$ & $P$ & & $H R$ & $95 \% \mathrm{Cl}$ & $P$ & & $H R$ & $95 \% \mathrm{Cl}$ & P & \\
\hline \multirow{2}{*}{$\begin{array}{l}\text { Gestational diabetes } \\
\text { mellitus }\end{array}$} & $<35 y$ & 0.841 & $(0.744,0.951)$ & 0.006 & \multirow[t]{2}{*}{0.744} & 0.748 & $(0.608,0.919)$ & 0.006 & \multirow[t]{2}{*}{0.751} & 0.842 & $(0.745,0.952)$ & 0.006 & \multirow[t]{2}{*}{0.749} \\
\hline & $\geq 35 y$ & 0.900 & $(0.755,1.072)$ & 0.238 & & 0.834 & $(0.622,1.119)$ & 0.227 & & 0.900 & $(0.755,1.072)$ & 0.238 & \\
\hline \multirow[t]{2}{*}{ Caesarean section } & $<35 y$ & 0.970 & $(0.909,1.035)$ & 0.354 & \multirow[t]{2}{*}{0.461} & 0.950 & $(0.852,1.059)$ & 0.353 & \multirow[t]{2}{*}{0.484} & 0.970 & $(0.909,1.034)$ & 0.348 & \multirow[t]{2}{*}{0.466} \\
\hline & $\geq 35$ y & 0.939 & $(0.839,1.052)$ & 0.281 & & 0.995 & $(0.947,1.046)$ & 0.850 & & 0.940 & $(0.839,1.053)$ & 0.282 & \\
\hline \multirow[t]{2}{*}{ Fetal distress } & $<35 y$ & 0.941 & $(0.826,1.072)$ & 0.362 & \multirow[t]{2}{*}{0.983} & 0.903 & $(0.724,1.125)$ & 0.363 & \multirow[t]{2}{*}{0.972} & 0.941 & $(0.825,1.072)$ & 0.360 & \multirow[t]{2}{*}{0.986} \\
\hline & $\geq 35 y$ & 0.924 & $(0.642,1.330)$ & 0.672 & & 0.872 & $(0.477,1.593)$ & 0.656 & & 0.925 & $(0.643,1.331)$ & 0.675 & \\
\hline \multirow[t]{2}{*}{ Preterm birth } & $<35 y$ & 0.886 & $(0.745,1.054)$ & 0.172 & \multirow[t]{2}{*}{0.264} & 0.816 & $(0.610,1.093)$ & 0.173 & \multirow[t]{2}{*}{0.263} & 0.886 & $(0.745,1.054)$ & 0.171 & \multirow[t]{2}{*}{0.264} \\
\hline & $\geq 35$ y & 0.773 & $(0.594,1.007)$ & 0.056 & & 0.648 & $(0.416,1.009)$ & 0.055 & & 0.773 & $(0.594,1.006)$ & 0.056 & \\
\hline \multirow[t]{2}{*}{ Low birth weight } & $<35 y$ & 0.911 & $(0.760,1.093)$ & 0.317 & \multirow[t]{2}{*}{0.145} & 0.855 & $(0.629,1.162)$ & 0.317 & \multirow[t]{2}{*}{0.145} & 0.930 & $(0.779,1.110)$ & 0.423 & \multirow[t]{2}{*}{0.145} \\
\hline & $\geq 35$ y & 0.721 & $(0.528,0.984)$ & 0.039 & & 0.575 & $(0.341,0.972)$ & 0.039 & & 0.721 & $(0.528,0.984)$ & 0.039 & \\
\hline \multirow[t]{2}{*}{ Macrosomia } & $<35 y$ & 1.139 & $(0.876,1.480)$ & 0.331 & \multirow[t]{2}{*}{0.784} & 1.245 & $(0.801,1.935)$ & 0.331 & \multirow[t]{2}{*}{0.425} & 1.138 & $(0.876,1.479)$ & 0.333 & \multirow[t]{2}{*}{0.784} \\
\hline & $\geq 35 y$ & 1.332 & $(0.511,3.476)$ & 0.558 & & 1.034 & $(0.724,1.477)$ & 0.853 & & 1.331 & $(0.510,3.474)$ & 0.559 & \\
\hline
\end{tabular}

Cox regression analysis were operated for exploration of associations, and adjusted for covariates including: age, BMl, parity, season of blood collected

${ }^{a}$ : Per one $S D$ increase. ${ }^{b}: P$ for interaction 
the detrimental influence of vitamin D deficiency or insufficiency in the reference group [7]. Increasing benefits might not exist for higher doses. Second, the vitamin D receptor is important for the utilization of vitamin $D$ $[31,32]$. The difference in vitamin $\mathrm{D}$ receptor gene polymorphism might help explain the ethnic heterogeneity [33]. This requires further confirmation in the future. Third, the studies were conducted during different trimesters of gestation, which might increase the difficulty of making comparisons; those studies conducted during an early gestational period might be advantageous for causal inference and early prevention.

Because $25(\mathrm{OH}) \mathrm{D}_{3}$ contributes most to the $25(\mathrm{OH}) \mathrm{D}$ concentrations, it has been used to represent $25(\mathrm{OH}) \mathrm{D}$ in many studies, and only a few studies have focused on $25(\mathrm{OH}) \mathrm{D}_{2}$. In our study, the results were generally consistent between these two subcomponents. The associations tend to be more pronounced in $25(\mathrm{OH}) \mathrm{D}_{2}$ than in $25(\mathrm{OH}) \mathrm{D}_{3}$ and might indicate the prominence of $25(\mathrm{OH}) \mathrm{D}_{2}$ over $25(\mathrm{OH}) \mathrm{D}_{3}$ for the prevention of related diseases. This theory merits further confirmation. Nevertheless, our results and others provide further evidence for the importance of a better early vitamin D status for the prevention of GDM, cesarean section, preterm birth, and low birth weight in a population with a high prevalence of vitamin D deficiency. Our results indicated that more consideration should be given to distinguishing between the vitamin D subcomponents, women pregnant at different ages, and women with more pregnancy complications in this field. Considering the high prevalence of vitamin $\mathrm{D}$ deficiency during pregnancy observed in China [2,3], it is a matter of urgency to call for the supplementation of vitamin $\mathrm{D}$, and more efforts should be made to improve the gestational vitamin D status of Chinese population.

Vitamin D deficiency was found to decrease vascular diameter within the labyrinth region and dysregulate placental development during early pregnancy in an animal experiment [34]. Vitamin D supplementation during early pregnancy might rescue this situation, while further supplementation might be futile after missing this time point [35]. Moreover, vitamin D supplementation during early pregnancy is likely to affect genetic information of systemic inflammation and immune responses involved in the development of gestational comorbidities (e.g., GDM, preeclampsia, and infection) as reviewed by Hollis et al [36] These mechanisms help to explain the beneficial influences of vitamin $\mathrm{D}$ for maternal and infant health and emphasize the importance of improving vitamin D status during early pregnancy.

Our study had several advantages. First, serum $25(\mathrm{OH}) \mathrm{D}$ concentrations were measured during an early gestational period, and with the retrospective cohort design, we assured the temporal sequence and avoided the possibility of causal inversion. Second, we studied multiple outcomes and conducted further analysis of the sub-component of vitamin $\mathrm{D}$ and a stratified analysis of gestational age, which provided a more comprehensive understanding of this field. There are also several limitations of our study. First, our study was limited by the lack of information on dietary vitamin D intake (including by supplement) and sunlight exposure during the pregnancy period. The obtained data were difficult to use for a retrospective study, while the use of blood indicators might be more precise than a dietary survey, so we adjusted the association for different seasons to attenuate their influence. Second, the $25(\mathrm{OH}) \mathrm{D}$ concentration was measured only once; we could not monitor the dynamic changes afterward or determine whether they were normalized after receiving vitamin $\mathrm{D}$ supplementation. However, the associations tended to be underestimated instead of overestimated. Third, Wagner et al. [37] and Mirzakhani et al. [35] indicated a 25(OH)D concentration $\geq 100 \mathrm{nmol} / \mathrm{L}$ in early pregnancy was optimal for the prevention of preterm birth and preeclampsia; however, the highest $25(\mathrm{OH}) \mathrm{D}$ concentration in our study is only $92.2 \mathrm{nmol} / \mathrm{L}$. Therefore, we were unable to perform the analyses using a threshold of $100 \mathrm{nmol} / \mathrm{L}$ and assess the influences of higher $25(\mathrm{OH}) \mathrm{D}$ concentrations. Finally, residual confounding might still exist, though we tried to control several potential covariates.

\section{Conclusions}

This retrospective cohort study showed the beneficial associations of early gestational vitamin $\mathrm{D}$ with outcomes of GDM, cesarean section, preterm birth, and low birth weight. More well-designed randomized clinical trials are needed for further exploration and confirmation of these results.

\section{Abbreviations \\ GDM: Gestational diabetes mellitus; LBW: Low birth weight; BMI: Body mass index; SD: Standard deviation}

\section{Acknowledgements}

We would like to thank Ye Shaoxin, Yang Xiaoming, Liu Haojing, Wang dong, and Huang Shaobing for their generous help in this study.

\section{Authors' contributions}

G.D.C. and Z.P.L. devised the idea and designed the study; G.D.C., T.T.P, P.S.L, Z.X.Z, D.X.L., D.Z.F. contributed to the primary data collection; G.D.C. and T.T. P re-examined the data; G.D.C., T.T. P, P.S. L, Z.X. Z, D.X.L., D.Z.F. contributed to the analysis of the data; G.D.C, and T.T.P wrote the original draft, which was revised by X.L.G. and Z.P.L.; X.L.G. and Z.P.L. supervised the study; and Z.P.L. administered the project. All authors have read and approved the manuscript.

\section{Funding}

This work was supported by the Basic and Applied Basic Research Foundation of Guangdong Province (No. 2019A1515110163, G.D.C.), and the Foundation of Bureau of Science and Technology of Foshan City (No. 1920001000294 , G.D.C.). The funding sponsors had no role in the design of the study; in the collection, analyses, or interpretation of data; in the writing of the manuscript, and in the decision to publish the results. 


\section{Availability of data and materials}

The datasets used and/or analyzed during the current study are available from the corresponding author upon reasonable request.

\section{Ethics approval and consent to participate}

The study was approved by the ethics committee of Affiliated Foshan Maternity \& Child Healthcare Hospital, Southern Medical University. The Affiliated Foshan Maternity \& Child Healthcare Hospital provided administrative permissions for the research team to access and use the data included in this research. Data were extracted from medical records, and the consent to participate was unavailable due to the retrospective design of the study and difficulty in reconnection; however, the private information was well protected.

\section{Consent for publication}

Not applicable.

\section{Competing interests}

The authors declare that they have no competing interests.

\section{Author details}

${ }^{1}$ Foshan Institute of Fetal Medicine, Department of Obstetrics, Affiliated Foshan Maternity \& Child Healthcare Hospital, Southern Medical University, Foshan 528000, Guangdong, China. ${ }^{2}$ Department of Medical Records, Affiliated Foshan Maternity \& Child Healthcare Hospital, Southern Medical University, Foshan 528000, Guangdong, China.

\section{Received: 11 February 2019 Accepted: 5 August 2020}

\section{Published online: 14 August 2020}

\section{References}

1. Saraf R, Morton SM, Camargo CA Jr, Grant CC. Global summary of maternal and newborn vitamin D status - a systematic review. Matern Child Nutr. 2016;12(4):647-68.

2. Yun C, Chen J, He Y, Mao D, Wang R, Zhang Y, Yang C, Piao J, Yang X Vitamin $D$ deficiency prevalence and risk factors among pregnant Chinese women. Public Health Nutr. 2017;20(10):1746-54

3. Zhou J, Su L, Liu M, Liu Y, Cao X, Wang Z, Xiao H. Associations between 25hydroxyvitamin $D$ levels and pregnancy outcomes: a prospective observational study in southern China. Eur J Clin Nutr. 2014;68(8):925-30.

4. Agarwal S, Kovilam O, Agrawal DK. Vitamin D and its impact on maternalfetal outcomes in pregnancy: a critical review. Crit Rev Food Sci Nutr. 2018; 58(5):755-69.

5. von Websky K, Hasan AA, Reichetzeder C, Tsuprykov O, Hocher B. Impact of vitamin $D$ on pregnancy-related disorders and on offspring outcome. J Steroid Biochem Mol Biol. 2018;180:51-64.

6. Nobles CJ, Markenson G, Chasan-Taber L. Early pregnancy vitamin D status and risk for adverse maternal and infant outcomes in a bi-ethnic cohort: the behaviors affecting baby and you (B.a.B.Y.) study. Br J Nutr. 2015;114(12): 2116-28.

7. Roth DE, Leung M, Mesfin E, Qamar H, Watterworth J, Papp E. Vitamin D supplementation during pregnancy: state of the evidence from a systematic review of randomised trials. BMJ. 2017;359:55237.

8. Hauta-Alus HH, Viljakainen HT, Holmlund-Suila EM, Enlund-Cerullo M, Rosendahl J, Valkama SM, Helve OM, Hytinantti TK, Makitie OM, Andersson S. Maternal vitamin D status, gestational diabetes and infant birth size. BMC Pregnancy Childbirth. 2017;17(1):420.

9. Khaing W, Vallibhakara SA, Tantrakul V, Vallibhakara O, Rattanasiri S, McEvoy M, Attia J, Thakkinstian A. Calcium and vitamin D supplementation for prevention of preeclampsia: a systematic review and network meta-analysis. Nutrients. 2017;9(10):E1141.

10. Zhang Y, Gong Y, Xue H, Xiong J, Cheng G. Vitamin D and gestational diabetes mellitus: a systematic review based on data free of Hawthorne effect. BJOG. 2018;125(7):784-93.

11. Zhang MX, Pan GT, Guo JF, Li BY, Qin LQ, Zhang ZL. Vitamin D deficiency increases the risk of gestational diabetes mellitus: a meta-analysis of observational studies. Nutrients. 2015;7(10):8366-75.

12. Aghajafari F, Nagulesapillai T, Ronksley PE, Tough SC, O'Beirne M, Rabi DM. Association between maternal serum 25-hydroxyvitamin D level and pregnancy and neonatal outcomes: systematic review and meta-analysis of observational studies. BMJ. 2013;346:f1169.
13. Qin LL, Lu FG, Yang SH, Xu HL, Luo BA. Does Maternal Vitamin D Deficiency Increase the Risk of Preterm Birth: A Meta-Analysis of Observational Studies. Nutrients. 2016;8(5):E301.

14. Rodriguez A, Garcia-Esteban R, Basterretxea M, Lertxundi A, Rodriguez-Bernal C, Iniguez C, Rodriguez-Dehli C, Tardon A, Espada M, Sunyer J, et al. Associations of maternal circulating 25-hydroxyvitamin D3 concentration with pregnancy and birth outcomes. BJOG. 2015;122(12):1695-704.

15. Ogawa K, Urayama KY, Tanigaki S, Sago H, Sato S, Saito S, Morisaki N. Association between very advanced maternal age and adverse pregnancy outcomes: a cross sectional Japanese study. BMC Pregnancy Childbirth. 2017;17(1):349.

16. Khalil A, Syngelaki A, Maiz N, Zinevich Y, Nicolaides KH. Maternal age and adverse pregnancy outcome: a cohort study. Ultrasound Obstet Gynecol. 2013;42(6):634-43.

17. Jolly M, Sebire N, Harris J, Robinson S, Regan L. The risks associated with pregnancy in women aged 35 years or older. Hum Reprod. 2000;15(11): 2433-7.

18. Li Q, Deng D. New medical risks affecting obstetrics after implementation of the two-child policy in China. Front Med. 2017;11(4):570-5.

19. Poel YH, Hummel P, Lips P, Stam F, van der Ploeg T, Simsek S. Vitamin D and gestational diabetes: a systematic review and meta-analysis. Eur J Intern Med. 2012;23(5):465-9.

20. Rostami M, Tehrani FR, Simbar M, Bidhendi Yarandi R, Minooee S, Hollis BW Hosseinpanah F. Effectiveness of prenatal vitamin D deficiency screening and treatment program: a stratified randomized field trial. J Clin Endocrinol Metab. 2018;103(8):2936-48.

21. Xu C, Ma HH, Wang Y. Maternal early pregnancy plasma concentration of 25-Hydroxyvitamin D and risk of gestational diabetes mellitus. Calcif Tissue Int. 2018;102(3):280-6.

22. Boyle VT, Thorstensen EB, Mourath D, Jones MB, McCowan LM, Kenny LC, Baker PN. The relationship between 25 -hydroxyvitamin $\mathrm{D}$ concentration in early pregnancy and pregnancy outcomes in a large, prospective cohort. $\mathrm{Br}$ J Nutr. 2016;116(8):1409-15.

23. Schneuer FJ, Roberts CL, Guilbert C, Simpson JM, Algert CS, Khambalia AZ, Tasevski V, Ashton AW, Morris JM, Nassar N. Effects of maternal serum 25hydroxyvitamin $\mathrm{D}$ concentrations in the first trimester on subsequent pregnancy outcomes in an Australian population. Am J Clin Nutr. 2014; 99(2):287-95.

24. Amegah AK, Klevor MK, Wagner CL. Maternal vitamin D insufficiency and risk of adverse pregnancy and birth outcomes: a systematic review and meta-analysis of longitudinal studies. PLoS One. 2017;12(3):e0173605.

25. Chen YH, Fu L, Hao JH, Yu Z, Zhu P, Wang H, Xu YY, Zhang C, Tao FB, Xu DX. Maternal vitamin D deficiency during pregnancy elevates the risks of small for gestational age and low birth weight infants in Chinese population. J Clin Endocrinol Metab. 2015;100(5):1912-9.

26. Amirlak I, Ezimokhai M, Dawodu A, Dawson KP, Kochiyil J, Thomas L, Abdulle AM. Current maternal-infant micronutrient status and the effects on birth weight in the United Arab Emirates. East Mediterr Health J. 2009;15(6): 1399-406.

27. Dawodu A, Saadi HF, Bekdache G, Javed Y, Altaye M, Hollis BW. Randomized controlled trial $(\mathrm{RCT})$ of vitamin $\mathrm{D}$ supplementation in pregnancy in a population with endemic vitamin D deficiency. J Clin Endocrinol Metab. 2013:98(6):2337-46.

28. Perez-Lopez FR, Pasupuleti V, Mezones-Holguin E, Benites-Zapata VA, Thota P, Deshpande A, Hernandez AV. Effect of vitamin D supplementation during pregnancy on maternal and neonatal outcomes: a systematic review and metaanalysis of randomized controlled trials. Fertil Steril. 2015:103(5):1278-1288.e1274.

29. Scholl TO, Chen X, Stein P. Maternal vitamin D status and delivery by cesarean. Nutrients. 2012:4(4):319-30.

30. Merewood A, Mehta SD, Chen TC, Bauchner H, Holick MF. Association between vitamin $D$ deficiency and primary cesarean section. J Clin Endocrinol Metab. 2009;94(3):940-5.

31. Chun RF, Peercy BE, Orwoll ES, Nielson CM, Adams JS, Hewison M. Vitamin $\mathrm{D}$ and DBP: the free hormone hypothesis revisited. J Steroid Biochem Mol Biol. 2014;144 Pt A:132-7.

32. Bikle DD, Gee E, Halloran B, Kowalski MA, Ryzen E, Haddad JG. Assessment of the free fraction of 25-hydroxyvitamin $D$ in serum and its regulation by albumin and the vitamin D-binding protein. J Clin Endocrinol Metab. 1986; 63(4):954-9.

33. Powe CE, Evans MK, Wenger J, Zonderman AB, Berg AH, Nalls M, Tamez $H$, Zhang D, Bhan I, Karumanchi SA, et al. Vitamin D-binding protein and 
vitamin D status of black Americans and white Americans. N Engl J Med. 2013;369(21):1991-2000.

34. Liu NQ, Ouyang Y, Bulut Y, Lagishetty V, Chan SY, Hollis BW, Wagner C, Equils $\mathrm{O}$, Hewison M. Dietary vitamin $\mathrm{D}$ restriction in pregnant female mice is associated with maternal hypertension and altered placental and fetal development. Endocrinology. 2013;154(7):2270-80

35. Mirzakhani $\mathrm{H}$, Litonjua AA, McElrath TF, O'Connor G, Lee-Parritz A, Iverson R, Macones $G$, Strunk RC, Bacharier LB, Zeiger R, et al. Early pregnancy vitamin D status and risk of preeclampsia. J Clin Invest. 2016;126(12):4702-15.

36. Hollis BW, Wagner CL. Vitamin D supplementation during pregnancy: improvements in birth outcomes and complications through direct genomic alteration. Mol Cell Endocrinol. 2017;453:113-30.

37. Wagner $\mathrm{CL}$, Baggerly C, McDonnell SL, Baggerly L, Hamilton SA, Winkler J, Warner G, Rodriguez C, Shary JR, Smith PG, et al. Post-hoc comparison of vitamin $\mathrm{D}$ status at three timepoints during pregnancy demonstrates lower risk of preterm birth with higher vitamin D closer to delivery. J Steroid Biochem Mol Biol. 2015;148:256-60.

\section{Publisher's Note}

Springer Nature remains neutral with regard to jurisdictional claims in published maps and institutional affiliations.

Ready to submit your research? Choose BMC and benefit from:

- fast, convenient online submission

- thorough peer review by experienced researchers in your field

- rapid publication on acceptance

- support for research data, including large and complex data types

- gold Open Access which fosters wider collaboration and increased citations

- maximum visibility for your research: over $100 \mathrm{M}$ website views per year

At $\mathrm{BMC}$, research is always in progress.

Learn more biomedcentral.com/submissions 